\title{
Dog-headed Creatures as the Other: The Role of Monsters in the Construction of the Croatian Identity
}

\section{Abstract}

This paper analyzes four reports concerning dog-headed creatures (pasoglavci) published in the late 19th and early 20th century in the Journal of Folk Life and Customs of Southern Slavs (Zbornik za narodni život i običaje Južnih Slavena). In order to determine who the dog-headed creatures represented in the Croatian folk culture of the time and why reports concerning them got published in the first ethnological journal in Croatia, it was necessary to study the concept of dog-headed creatures from the perspective of the process of othering. The conclusion was that the specific historical and cultural circumstances that existed in the area from which the reports originated stimulated the construction of the idea that the dog-headed creatures existed, which was used both to demonize other ethnoreligious groups and to create a positive image of the original group's own identity ${ }^{[1]}$

Keywords: dog-headed Creatures, Croatian folk culture, the Other, identity, late 19th century

\section{Introduction}

In 1896, the Croatian Academy of Sciences and Arts started publishing the Journal of Folk Life and Customs of Southern Slavs (Zbornik za narodni život i običaje Južnih Slavena, hereafter: Journal), which is usually considered the first ethnological journal in Croatia ${ }^{[2]}$ In its first issue, besides papers on Croatian folk traditions concerning childbirth, weddings, and passing away, a considerable number of papers on folk beliefs were published. Among these was a short paper on 
the pasoglavci ${ }^{[3]}$ (dog-headed creatures). Its author, Dragutin Hirc, was a Croatian naturalist, mountaineer, and publicist, who had, while conducting his scientific field research, also gathered materials concerning Croatian folk culture. According to his notes on folk beliefs, dog-headed creatures occurred in eight places in Croatia and were usually described very similarly. They had a human body and a canine head, with one eye in the middle. In some retellings, they had four legs and a tail resembling that of a horse. The place of their origin was described as dark and distant land rich in gemstones. The land was supposedly guarded by an army which did not let them pass into "our" country but directed them toward the Russian Empire. However, some retellings mention that the Russians defended themselves from them with cannons, thereby also defending "us" (the Croats). The reports emphasized that the dog-headed creatures crossed borders because they used to live in nearby swamps during the period when the Ottomans ruled over some of the Croatian lands (15th-18th century). They were prone to attacking Christians, who feared them greatly because the dog-headed creatures most of all delighted in devouring Christians, especially Christian women, whose breasts they would bite off. The only defense against them was to run away and hide under some manure so they would not smell the scent of humans ${ }^{[4]}$

In the sixth issue of the Journal, published in 1901, in the text of Ivan Zovko, a collector of folk customs of Croats in neighboring Hercegovina, anthropophagy is also mentioned as one of the most common characteristics of dog-headed creatures. Zovko recorded that he heard from the local Croats that dog-headed creatures used to defile both Christian and Muslim cemeteries and eat cadavers. To defend themselves from this menace, people would place menhirs on top of the graves so that the dog-headed creatures would not disturb the deceased ${ }^{[5]}$ The tenth issue of the Journal, published in 1905, brought another short text on the dog-headed creatures, who were, in this instance, described as deformed children, born as a divine punishment for his mother's or some of his relatives' sins ${ }^{[6]}$ The next issue of the Journal, from 1906, brought yet another text on the creatures, written by Ivan Krmpotić, also a collector of folk beliefs. The peasants' tales he recorded resembled the fairy tale of Hansel and Gretel. A brother and sister were thrown out of their father's home by their stepmother, and during their wanderings, they stumbled upon a valley with a house in which an old female dog-headed creature lived. She had only one eye on her head, and her legs were like those of a goat. As the children were hungry, she offered them a human arm 
to eat, but they refused to do so. To keep them safe from her voracious sons, who were out hunting and who would have surely eaten them upon their return, the old dog-headed female hid the children, but she betrayed them as soon as her sons caught the scent of Christian souls in her house. They decided to eat one child right away and to make the other one fat for the pot. However, the children outwitted the dogheads gullible, killed them, and ran away. Thenceforth they would not enter any houses unless they were sure that their inhabitants were Christian. Upon hearing that their father had passed away, they traveled back home and burned their stepmother ${ }^{[7]}$ These four reports, published in the first issues of the Journal at the turn of the 20th century, make it clear that the dog-headed creatures were presented in Croatian folk culture as monstrous beings, to whom a series of negative characteristics was ascribed, and whom no one would want to live close to. Nevertheless, the reports listed here demonstrate that groups or individuals to whom the characteristics of dog-headed creatures were ascribed might have existed in the past, and that they, with time, found their place in folk beliefs. Therefore, it is my intention to investigate, in this paper, who the dog-headed creatures from the listed reports were representing, for what purpose that construct was used, and why reports on them were included in the first issues of the oldest ethnological journal in Croatia.

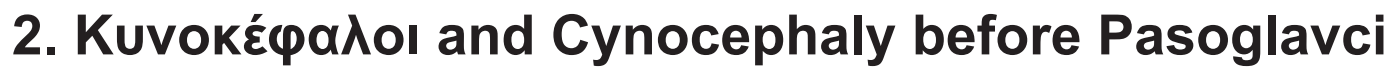

The dog-headed creatures appearing in the reports in the Journal are by no means an unfamiliar concept. In fact, the concept was already present in ancient histories and travelogues, which

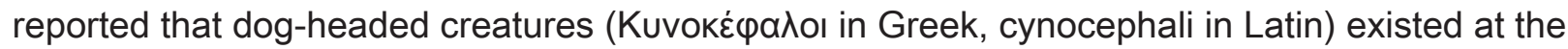
edges of the then known world. We find them in distant countries such as Ethiopia, Sudan, India or stretches of the Asian steppes, where they would, together with other monsters such as the blemmyae (humans with no heads and with a face on their torsos), skiapods (meaning "shadow foot”), amazons (breastless women), cyclops (round-eyes), and many others, represent the members of monstrous, mythical peoples with whom first the Greeks, and then other Europeans, came in contact ${ }^{[8]}$ In the ancient descriptions of monstrous peoples, precisely the dog-headed creatures were most commonly featured (Friedman 15). Herodotus reported on them as early as the 5th century BCE in his Histories, placing them in Lybia, where they supposedly lived together 
with unicorns and headless men with eyes on their chests ("Kinokephaloi"). Ctesias of Cnidus, a Greek physician at the Persian court, wrote in his Indica that dog-headed creatures existed in the mountains of India, reporting that they had canine heads and clad themselves in beast skins. They had no language, but they communicated among themselves by barking and with other peoples by waving their arms about as if they were deaf and dumb (Ibid.). In the first century, the Roman author Pliny the Elder (23-79) appropriated Ctesias's ideas about mythical peoples in his Naturalis Historia, a work resembling an encyclopedia, and expanded on them using the descriptions of the Greek historians Megasthenes (c.350-c.290 BCE) and Pseudo-Callisthenes (3rd century BCE), who wrote on the conquests of Alexander the Great (Friedman 8). Therefore, Pliny expanded the description of dog-headed creatures by adding that they lived in caves in the mountains of India, that they had large teeth and breathed fire, and that they ate raw venison meat, hunting the animals by using their large claws ("Kinokephaloi"; Friedman 15).

Considering the existing anthropological research, we can assume that the monstrous peoples and tribes, among whom the dog-headed creatures were the most commonly featured and on whom the ancient authors wrote, did not actually exist. They were the result of distorted interpretations of what the travelers saw or the authors heard. The contemporary reports were based on a rudimentary or non-existent knowledge of the geography and fauna of distant lands and lacked the knowledge of the culture, everyday life, and behavior of foreign peoples. Some of the descriptions were formed on the basis of real physical attributes and cultural phenomena of the inhabitants of distant lands, leading some to recognize the dog-headed creatures in the totemic animals of certain Indian and Mongolian tribes (Shafer 500; Rehn 123) - the Egyptian god Anubis, African baboons, or amalgams of steppe riders and their horses, while the local languages, incomprehensible to ancient recounters, were interpreted as canine barking or mumbling, from which the word "barbarian" came (Friedman 29). Stories about monstrous inhabitants of the edges of the world were prone to emphasizing paradoxes and sensations, which, along with the dubious nature of its assertions, were characteristic of the then-popular genre of travelogues (6). Additionally, reports on dog-headed creatures, such as the ones by Ctesias, abound in typographical errors, bad transliterations, and more recent adjustments of their texts (Shafer 502), which contributed to the distorted idea of nations distant from the world's "center." However, it is 
necessary to emphasize that such constructs, steeped in sensationalism reinforced by the ethnocentric views of the Europeans, were transferred into the later centuries, during which the motif of dog-headed creatures was used to marginalize and demonize the religious and ethnic Others, both those beyond and within the Western, "civilized," Christian world.

Due to the triumph of Christianity during the European Middle Ages, the fear of the malevolent Other accelerated the process of constructing monsters at the edges of the Christian, "civilized" center. As early as the 5th century, Aurelius Augustine had, in his De Civitate Dei, tried to explain what the dog-headed creatures were, writing that their "canine heads and barking show that they are more beasts than men" (Augustine 419; bk. 16, ch. 8,1). He concluded that the dog-headed creatures and other monstrous races of humans "of which pagan histories tell us," either do not exist, or are not human, or they are part of the mankind descending from Adam (421; bk. 16, ch. $8,2)$. By this statement, Augustine did not deny the existence of monstrous races of humans but explained their possible existence as an act of God's will, which was not to be questioned. In other words, dog-headed creatures and other monstrous peoples, groups, and individuals existed as a mystic message from God to mankind (419; bk. 16, ch. 8,1).

The possibility that God created the monstrous races contributed to the continuing construction of dog-headed creatures during the subsequent centuries. On the occasions on which Europeans came into contact with other groups, whether those coming to Europe or those encountered by Europeans on their voyages or conquests, the image of the monstrous Other, shaped on the basis of mythical and archaic cosmogonies, propelled by the writings of both Christian and ancient writers, was perpetuated (Kocój 274). Let us list just a few examples. In the 8th century, Paul the Deacon reported in his Historia gentis Langobardorum that the dog-headed creatures lived in Lombard military camps and drank the blood of their enemies (Paul the Deacon; bk. 1, ch. 11; Rehn 118). Saint Christopher, a 3rd-century saint, was portrayed in the early Middle Ages as having a canine head because of a Byzantine legend, according to which he met the boy Jesus, who baptized him in the Land of Canaan. The Land of Canaan (cananeus) was subsequently mistranslated into Latin as the land of the canine (canineus) - i. e., the land populated by dogheaded creatures. This was intended to signify that the wild peoples, such as the dog-headed creatures, could be converted to Christianity and adapt themselves to the ideas coming from the 
"center" (Friedman 71; Rehn 138; Jaritz 30). During and after the Mongolian invasions of Europe in the 13th century, the idea of monstrous races coming from the Asian steppes additionally strengthened. Nomads who ate raw meat were easily "transformed" into dog-headed creatures who feasted on human flesh (Rehn 120; Sardelić 9). In the next century, the idea of dog-headed creatures was spread through Europe by the exceptionally popular travelogue The Voyage and Travels of Sir John Mandeville, which mentioned there were dog-headed creatures (Cynocephales) living on the Nicobar Islands (Nacumera) (Mandeville 130; Mosely). The existence of dog-headed creatures and other monstrous races from the Asian steppes, India and distant islands found its place in the medieval and early modern visual culture as well (Jaritz). In the geographical maps, it was clear which part of the world was the center since the periphery brimmed with monsters (Rehn; Duzer). This is why Martin Waldseemüller had, on his geographical map Carta marina from 1516, placed one group of dog-headed creatures in the Indian subcontinent, and another in the Asian steppes, where they were accompanied by the mythical, demonic tribes of Gog and Magog (Duzer 222, 226). During the Age of Exploration in the early modern age, Europeans would "discover" that there were monstrous races, including dog-headed creatures, living in the newly discovered territories: "Dog-headed creatures turn up regularly in representations of the edges of the world as well as in the center; and when new edges of the world emerged, dog-headed figures were among the first ones discovered to have been living there" (Jaritz 29). In this process, they were often ascribed with cannibalistic tendencies because the early modern folk considered nonEuropeans evil anthropophagi, the eaters of Whites, and their cultural products. This was radically different from the romantic notion of the noble savage, who was submissive and ready to be converted by European colonizers (Budasz 3). Such accounts were included in various writings to clarify their message and to increase its effect. Monsters were often used as a means of delineating boundaries and expressing the difference between morality and sin, or conformity and non-conformity (Olszewska 142). Such a principle was present even in the folk tales of Medieval Ashkenazi Hebrews, who were themselves through history referred to as monsters and dogheads by other Europeans, but nevertheless invented their own monsters and dog-headed creatures in order to depict the laws and behavior of Others as sinful and wrong (Rotman 102, 108). In other words, European history and culture abounded in dog-headed creatures, whether those menacing it from dark, distant lands or those within its own domain. 


\section{The Constructing of Dog-headed Creatures and/or the Monstrous Others}

Among the multitude of writings, of which we mentioned just a few, one deserves a special mention

- the famous romance about the life of Alexander the Great, which was also used by Pliny the Elder as a source of information, and which, according to some authors, especially influenced the idea of dog-headed creatures and other monstrous peoples in the European (folk) culture (Jokić 258-59; Rehn 112; Šmitek 241). The Alexander Romance, the core of which was written while Alexander himself was still alive, abounds in descriptions of monstrous peoples he encountered during his conquests of Persia and India. The work, attributed to an unknown author called Pseudo-Calisthenes (around 300 BCE), was edited a number of times and translated into various European languages from the 4th until the 17th century, and adapted into a medieval romance. Due to its intriguing and exotic contents, it was very highly valued and widely read (Dürrigl 8). At the beginning of the 17th century, its Croatian version, entitled Aleksandrida, was published in Latin script, after it was transliterated by the copyist Ivan Derečkaj (loannes Derechkay) from a (western) Cyrillic template, which originated in the 16th century (Dürrigl 21-22, 26-33). The existence of this romance, which is known to have been spreading ideas of monstrous peoples from distant lands across Europe, in Croatian, and in Latin script, leads us to the conclusion that it may have influenced the folk traditions and stories about dog-headed creatures which were published in the Journal[9] Therefore, let us see what the Croatian Aleksandrida has to say about Alexander's encounter with dog-headed creatures:

I zemlju njihovu za sedam dan prošad i tak pasjoglavom dojdoše: imaju vse telo kak človik, a gubac pasji. I tak zemlju njihovu za deset dan prošad k moru nikomu dojdoše. (And upon passing through their land in seven days, he came upon the dogheads: their whole bodies are human, and their snouts are canine. And so, upon passing through their land in ten days he came upon some sea; my trans.). (Hrvatska Aleksandrida 146, ch. 44)

If we look more closely at the only sentence that mentions dog-headed creatures in the Croatian Aleksandrida, it becomes obvious that, other than having a human-like appearance and canine 
snouts, no attributes or characteristics of the dog-headed creatures mentioned in the reports from the Journal are present in it. In fact, these dog-headed creatures appear to be fairly harmless, considering that Alexander the Great nonchalantly passed through their land in ten days, after which he came upon same sea. However, Jasmina Jokić, a Serbian folklorist, determined that the Serbian version of the Alexandrida, which originated in the 15th century and was modeled on the same proto-version from the earlier centuries as the Croatian one ${ }^{[10]}$ also mentions pasoglavci, even though the original version of Pseudo-Callistenes ${ }^{[1]}$ does not use such a term for those beings (259, cf. Pseudo-Callisthenes 113-14). Jokić stated that the concept of dog-headed creatures in the Serbian version (which also goes for the Croatian version, as it was modeled on the same exemplar) was developed from the events described in the previous chapter of the Alexandrida. In that chapter, it is described how Alexander and his army encountered some wild men who were (in Pseudo-Callistenes's version) barking like dogs (the Serbian and Croatian versions do not mention the barking) and were two fathoms tall. Alexander ordered a naked woman to be sent over to them so that he would see how they would react to her. One of those savages started biting the woman, due to which a fight erupted between the wild men and Alexander's soldiers, and during the fight, the wild men would devour anyone whose blood they would manage to shed (Hrvatska Alexandrida 144-45, ch. 43v-44r; Jokić 259; Pseudo-Callisthenes 114). Therefore, Jokić noticed that the original Pseudo-Callistenes's variant mentions only the barking variety of wild men, not a distinct people with canine heads/snouts called the dogheads ( pasoglavci). On the other hand, the Serbian (and the newer Croatian) version does not mention the barking, but the next chapter does briefly mention the dogheads, i. e., humans with canine heads/snouts through whose land Alexander had been traveling for ten days (Jokić 259). In the corresponding place in Pseudo-Callisthenes's original, it is only stated that Alexander and his army were traveling through the darkness for ten days before reaching the shore (Pseudo-Callistenes 115). It is, therefore, valid to assume that the episode with Alexander meeting the fearsome wild men, who spoke in canine sounds and displayed cannibalistic urges, evoked the concept of dogheaded creatures already existing in South Slavic oral culture, causing the dogheads to be inserted into the part mentioning the passage through darkness. The descriptions in the original version obviously corresponded with the concept of dog-headed creatures already familiar to Southern Slavs, and therefore the exemplar on which both the older Serbian and the newer Croatian 
Alexandrida were modeled, using the word pasoglavci as an adequate term and descriptor for the wild men whom Alexander had encountered in the previous chapter. With that in mind, it is appropriate to assume that the romance of Alexander the Great and his conquests indeed did shape a part of the idea of dog-headed creatures in Croatian (and Serbian) folk culture, considering that the Alexandrida added savagery and cannibalism to the already existing name and physical description of the pasoglavci. In fact, the examples listed in the Journal describe the dog-headed creatures as cannibals, and the part about them delighting in biting off women's breasts (Hirc 229) certainly sounds much like the episode with the biting of the naked woman in the original Alexander Romance. However, if the term pasoglavac - a man with the head/snout of a dog - was inserted into the Alexandrida, it is apparent that such a character had already existed before the exemplar on which the Croatian and Serbian versions of the romance were based.

Of course, this instance begs a number of questions regarding how and when the image and the concept of dog-headed creatures were included in the South Slavic and perhaps other European versions of the Alexandrida. It also remains to be examined which writings, besides the Alexandrida, influenced the construction of dog-headed creatures in folk culture, which subsequently "reintroduced" them into the written medium. However, due to the constrictions of this paper, we will not delve into these questions. It is more important here to note that the concept of dog-headed creatures was evoked by the descriptions of cannibalism and bloodthirsty savages who communicate by barking and that it was added to the place in which Pseudo-Callisthenes's version of the text mentions a dark country. In other words, the concept of dog-headed creatures was "activated" when it was necessary to emphasize that the text speaks of the monstrous Other. This demonstrates that the South Slavic folk culture possessed a mechanism, which can be traced as far back as Herodotus's writings, so by constructing dog-headed people, they indicated what was foreign, distant, repulsive, and sinful to "us." Ascribing monstrous attributes to other religious, ethnic, and racial groups is a clear reflection of the process of othering by which the members of the "center" strive to emphasize that their culture is exalted, civilized, true, and moral as compared to the culture of Others, who are wild, primitive, immoral, and deceitful to such a degree that they might as well be imagined as monsters or half-animals. The Western culture, as Edward Said noted, also attempts to affirm its strength and identity by positing itself as being contrary to the 
periphery (the Orient), as its surrogate of sorts, or even its dark Ego, due to which we can speak of a Western manner of dominating, restructuring, and ruling the Other (17). Defining someone as an Other also implies drawing whether real or symbolic borders. This leads to creating social, cultural, and moral categories and, as a consequence, a hierarchical evaluation of various cultures (Kastoryano 79). In this process, in which it is imperative to place one's own culture and identity be it religious, linguistic, or racial - at the top of the hierarchy, the Others are the ones who suffer damage. They are the ones whom we, while forming our own identity, insult, kill, rob, or withhold aid to when they are in need, simultaneously holding the moral high ground by claiming they are the lower entities. Such moral requirements were recorded in all human societies (Tylor 4-5). Let us consider just the example of forming a religious identity, which is strongly present in the process of othering. It often takes the form of fundamentalism which can be, as Ernest Gellner notes, best defined by that which it rejects (11). Referring to the philosophical considerations of Søren Kierkegaard, Gellner emphasizes that religion, in its essence, is not the conviction in the veracity of a doctrine but a complete surrendering and adhering to a position with is inherently absurd or, rather, insulting. In order to gain an identity, we have to believe in something that deeply insults our reason. In order to live, we must believe in something which is terribly hard to believe. One cannot live by merely believing that something is possible, "[t]hat is the existentialistic revolution that binds faith to identity rather than to proof" (Gellner 12). In that sequence, the dog-headed creatures, as an expression of othering, can be perceived as a construct, for which it is not important to prove that such creatures really exist, but which is seen as alterity through which "our" own identity is constructed, while not caring about the consequences it might have for the Others. Even though it is difficult or even insulting for our reason to believe that the Others really are dogheads, we do adhere to such a possibility because it helps us to synthesize our own identity. The insertion of dog-headed creatures into the Alexandrida, which were mentioned by ancient writers, which we encountered in the newly discovered countries in the modern age, and which we found in reports on Croatian folk culture, should be considered in that perspective.

\section{Dog-headed Creatures and the Concept of Otherness in Croatian Folk Culture}


If we consider the examples listed in the Journal, it is obvious that Croatia was not immune to demonizing different ethnic and religious groups by constructing dog-headed creatures as the Others. The examples themselves demonstrate whom the Croats at the time considered Others. The dog-headed creatures in these examples lived in the swamps when some parts of the Croatian historical lands were under Ottoman rule, the Russian cannons (which were in the east) did not allow the pasoglavci to come to " $u s^{\lceil 12]}$ and the dog-headed creatures who assaulted Christians had four legs and a tail (Hirc 229). These descriptions lead us to consider that the fourlegged dogheads might have been the Ottomans, who came from the east with their formidable cavalry, who assaulted Christians, and after whose occupation of Croatian territories the dogheaded creatures appeared. Folk tales from neighboring Serbia also demonstrate that the Ottomans were associated with dogs or half-dogs. They say that a Turkish emperor's daughter was impregnated by a dog and gave birth to nine pups, which were nursed by a sow. For this reason, according to the folk tales, the Ottomans did not eat pork, as they saw the pig as their wet nurse (Đorđević 480-481) ${ }^{[13]}$

If we look at a map of the Croatian historical lands during a time that immediately preceded the reports in the Journal, it becomes apparent that all of them came from the part which, over many centuries, formed the frontier with the Ottoman Empire (see fig. 1).

Although there was no direct contact with the Ottomans for more than two decades at the time when the Journal was first published, the data listed here lead us to the conclusion that the contact with the Ottomans and their presence in this area, which lasted for several centuries, influenced the shaping of a negative image of them as the monstrous Others. 


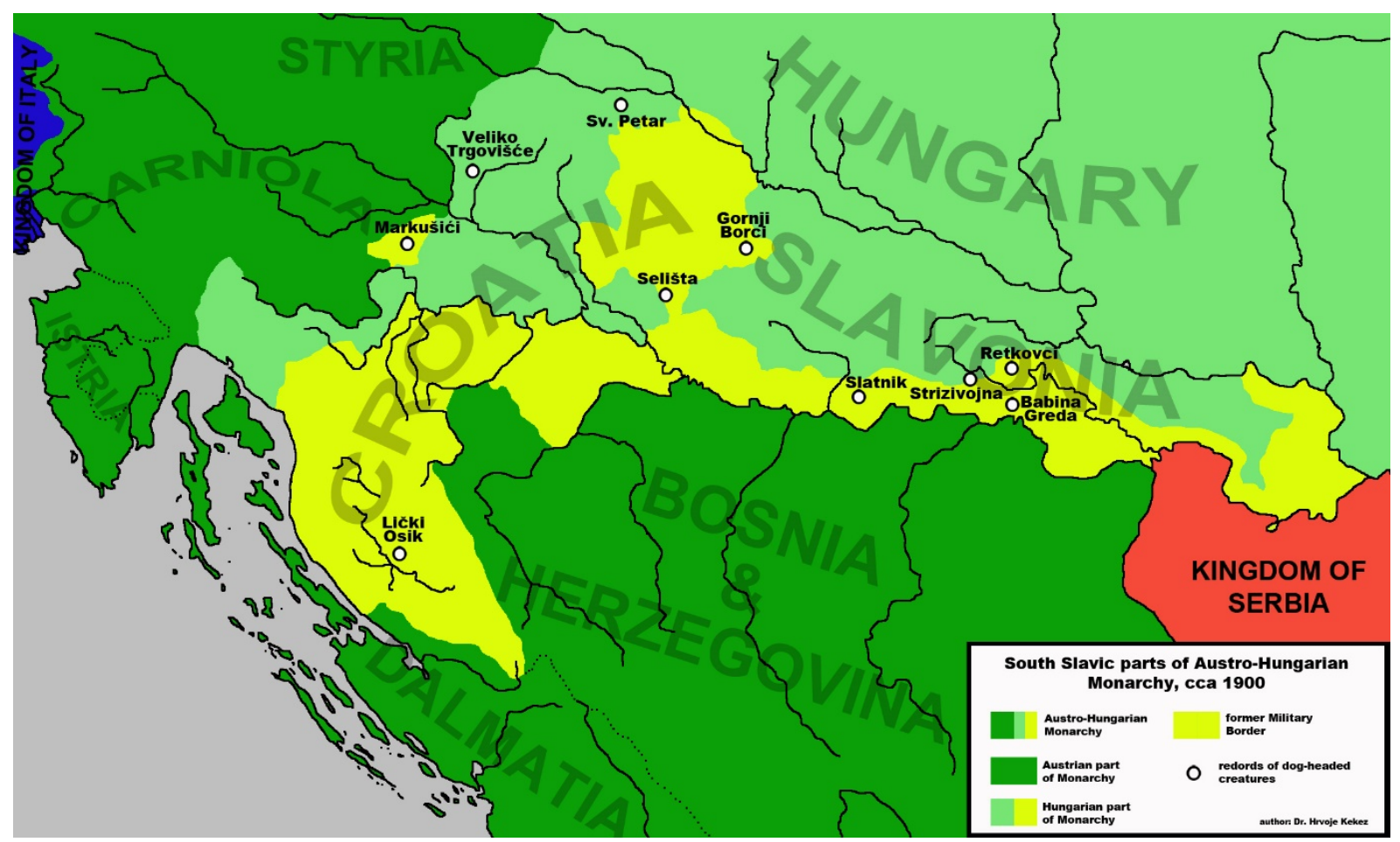

Figure 1. The map of South Slavic parts of Austro-Hungarian Monarchy, cca 1900.

This theory is corroborated by two folk tales about dog-headed creatures recorded in the 19th century among the Orthodox populace at the border of Croatia and the Ottoman Empire by the Orthodox priest Nikola Begović. The first is about the džiganti (giants), who were also called pasoglavci (dogheads), because they had canine heads and ate Christians, "just as those Turkish dogs do" (Begović). The second tale is about Ottomans with canine tails, due to which they cannot sit down, so they squat instead, and "a Christened soul smells appetizingly to them, to them our blood tastes sweet" (242).

Ottoman attacks and conquests of the Croatian lands began as early as the end of the 15th century. Due to the increasing intensity of their westward expansion, the Habsburg monarchs formed the Military Frontier in 1578, which served as a military-territorial defensive belt stretching from the Adriatic to the Carpathians (Moačanin 77-108). As the Croatian historical lands (Croatia, Slavonia, and Dalmatia - see fig. 1) were parts of the Habsburg realm, and due to their constant contact and conflict with the Ottomans, large areas of their territory became part of the Military Frontier and functioned according to specific social, military, and political laws (212-304), and were part of the territory that was called "Antemurale Christianitatis" (the Bulwark of Christendom) as early as the 15 th century! ${ }^{[14]}$ 
After the Ottomans were defeated in the Siege of Vienna in 1683, and after peace was made with them in Sremski Karlovci in 1699, the Habsburg rulers reclaimed some of the territories previously lost to the Ottomans, including parts of the Croatian lands. However, the Military Frontier continued to function as a useful military framework, which, among other things, continued serving as a border toward the southeast, where the neighboring Bosnia and Hercegovina remained a part of the Ottoman Empire. Such conditions lasted until the Austro-Hungarian occupation of Bosnia and Hercegovina in 1873, after which the Military Frontier was demilitarized and, in 1881, included in the contemporary Croatian substate (381).

Difficult living conditions, several centuries of isolation, the permanent danger that comes with living on the frontier, and an enemy coming from distant eastern lands, together evoked a monstrous character from the collective memory - the menacing and terrifying dog-headed creature. It is therefore not surprising that the aforementioned reports on dog-headed creatures from Croatia came precisely from these locales, which used to be within the Military Frontier or directly on its border. This is where the authors of the texts on dog-headed creatures in the Journal found the deep-seated notions about the dogheads. The Military Frontier was a liminal locale in which menace and endangerment constructed the monstrous image of the Other, which, on the one hand, evoked fear, and on the other, incited to aggression. Fears, desires, and anxieties of a given society at a given time are incarnated in its ideas of monsters, and the body of the monster is, therefore, in its entirety, the body of the culture that shaped it (Cohen 4). Monstrous bodies, monstrous languages, monstrous diets, and monstrous places are all forms of discourses, which, to a great extent, depend on the culture from which they originated (Levanat-Peričić 14).

Here it should finally be stated that it was not without a reason that the European culture, starting with the ancient Greeks, had chosen a man with a canine head as a representation of the Other, i. e., the monstrous peoples menacing its borders. By ascribing a disharmony of bodily proportions, a deviant appearance, and theriomorphic attributes to other groups, the observers looking out of the "center" delineated those groups' characters and associated them with the supernatural and the monstrous (Olszewska 184). Such a practice was dominant during the many stages of European history in which women were being accused of witchcraft because any bodily anomaly was interpreted as a result of a supernatural influence or even as a replica of something supernatural. 
Thus, the witches, who were considered an embodiment of evil, were recognized by their ugly appearance due to the belief that the outward appearance corresponds to the inner one (Šešo, "Which woman" 203; Mencej 218-21). In the case of the dog-headed creatures, we face humananimal hybrids, the construction of which conveys that such beings are neither human nor animals (Rehn 114). As animals themselves are the "Ultimate Other" to humans, an irreversible symbol of alterity (Borkfelt 3), by placing the head of an animal on a human body a strong message is conveyed - these groups are not like us. They are creatures whose animalistic/canine nature permeates them to such an extent that it dominates their physical appearance. However, why the dog was chosen to be the animal whose attributes were used for the othering of the monstrous Other was best explained by Nikola Visković, a Croatian cultural animalist, who wrote on the dog in the Croatian culture and culture in general and discussed its characteristics and notions about it. According to Visković, the dog is a humanized and cultivated animal. Humans altered its body and its natural abilities for it to suit their needs. The dog is a social creature, and it is instinctively subordinate to humans. It is well-disposed to fit in the hierarchical system. The dog is versatile and strongly dependent on the man who feeds it and commands its behavior. By its very nature, the dog is obedient and likes to be commanded over. It is possible to instrumentalize it for many purposes. With the dog's help, man compensates for the senses and abilities he lacks. The dog seeks authority and control, and it is possible to use it to attack other humans. The dog is obedient only to its master and to its pack and at the same time hostile, aggressive, and distrustful of others, so its urges and instincts are easily manipulated and used against other humans and animals. Among dogs, we find strongly developed concepts of "us" and "them." In Europe's history, as well as among Asian and Muslim peoples, the dog was considered a filthy and shameful creature. It was a scavenger of refuse and the eater of corpses. Finally, the dog is the image of its master (202-06). Considering Visković's views, we can suggest that the peoples of Croatia and Europe saw in the Ottomans, the Huns, the Indians, the Ethiopians, and others the characteristics of the dog. Savage hordes from the East and other peripheries of the known world were nothing but packs of dogs, wild dogs, but also humanized. They were hierarchically organized because of their subordination to the sultans and other masters. They were hostile to us and obedient among themselves. They were scavengers of refuse who lived in dark lands. Dogs have been deemed an appropriate image of the Ottomans. Therefore, the Ottomans were the dogs. 
The dog-headed creatures in our examples were also a reflection of a culture, which had accepted Christian imagery, and within it the supposed threat that had for centuries been coming from the east. No matter whether the enemy was coming from the outside, in which case they would be equated to demi-dogs, or from within the society itself, in which case they would be described as old and ugly witches, vampires or werewolves, their monstrosity would be associated with antiChristian concepts (Kocój 275). Their deformed appearance would signify the divine punishment for their deviant behavior and wickedness. Those perceived as sinful were often portrayed as being physically deformed. This tactic was used to demonize perceived enemies of Christendom, to whom inhuman practices (such as cannibalism) were often attributed (Olszewska 142). The examples listed in the Journal also strongly emphasize the dichotomy of "us," as Christians, and the cannibalistic dogheads who want to devour "us" precisely due to our adherence to Christianity. Thus, the dog-head is "a terrible man, who attacks Christians, eats them and so sustains himself" (Hirc 229), and the female dog-head, who offered the wandering children a bowl of meat with a human arm in it, is also a cannibal (Krmpotić 157). Of course, the children refused to eat human flesh because they were Christian, and from that moment on, they were careful to enter only houses of those who knew how to cross themselves (158). Anthropophagy, as one of the main characteristics of the dog-headed creatures, is also emphasized in the example in which they are described as defilers of graves and eaters of corpses. However, in that case, we cannot see the Ottomans as being the dogheads, as the report states that they would dig up both Christian and Muslim graves (Zovko 142). Still, it should be noted that this example originated in the neighboring Bosnia and Hercegovina, which was a part of the Ottoman Empire until the Austro-Hungarian occupation, and which was, for several centuries, marked by a coexistence between Christians and Muslims. Therefore, some specific ethnoreligious groups were not (so we assume) described as dog-headed creatures. Nevertheless, the concept of dog-headed creatures was applied in order to other the group of those who defile graves, most likely grave robbers, and who thus defy the laws of both religions, which prescribe regarding the deceased that "no one should disturb them in their eternal homes" (Ibid.). The concept of dog-headed creatures was therefore used to point out dishonorable, immoral deeds, i. e., those which deviate from "our," approved cultural norms. Although ascribing cannibalism to Others predominates in this process, physically deformed 
children were also labeled as dog-headed creatures, in order to, by stigmatizing the child, other its mother or some of its kinsmen, due to their disrespect for Christian or other socially approved norms (Filakovac 148). It should also be noted that in Croatian folk culture, such a practice was not limited to the concept of dog-headed creatures, but that undesirable and reviled individuals and groups were also stigmatized by the creation of ideas of monstrous creatures existing within the society - primarily of werewolves and witches. Thus, recorded folk beliefs demonstrate that, from the perspective of Catholic Croats, those who turned into werewolves after their death were previously evil men, but also Muslims, Orthodox Christians, and, in more recent times, communists or atheists (Šešo, Živjeti s nadnaravnim 173-203). In rural communities, those considered to be witches were mostly ugly, old, disabled, or even promiscuous or flamboyantly lecherous women (Ibid.). And, while the constructing of ideas about witches and werewolves in Croatian folk culture was directed, to a greater degree, toward individuals and groups within the community itself, the label of dog-headed creatures was mostly applied to foreign groups, or those unknown to "us," who threaten from beyond the borders of "our," cultivated, familiar world. Therefore, the dog-headed creatures were not the demonic Others merely due to the cannibalistic and savage attributes assigned to them, but also because they inhabited dark countries, swamps, and distant places, from which they menaced the Christian world. The aforementioned example with the Russian cannons guarding the frontier clearly states that, from "our" point of view, the land of the dogheaded creatures is dark (Hirc 229), but it also possibly confirms that the dogheads were actually the Ottomans, as the latter had periodically been at war with the Russian Empire until 1878 (Barry). It is very likely that an echo of those wars found its place in the aforementioned example, where it serves the purpose of othering the Ottomans as dog-headed creatures, who threaten the Christian world from beyond its frontiers. The concept of monsters who existed on the periphery, i. e., in places distant from the center, was already mentioned in this paper, and it also existed in the Croatian folk culture, its purpose being to mentally place the Other, who was undesirable and terrifying, in dark areas and wildlands. This was meant to demonstrate that the Others are distant from the civilized center, which is ruled by order, law, and art that makes us human (Friedman 30). However, the dark land of the dogheads simultaneously represents a place with many riches, such as gemstones (Hirc 229). In this manner, the Others' domain, besides being frightening, also becomes a place of attraction (Kocój 272) and the supernatural creatures and demons, such as the 
dogheads, also evoke the sense of awe due to the strength and power that is usually attributed to deities, but demons as well (Caroll 168). Through the process of shaping the monstrous Other, which manifested itself in folk culture as well, people expressed their own anxieties and insecurities caused by social changes and articulated their fear of the unknown, which indicated their wish for stability and security (Valk 236). By doing so, people would somewhat alleviate the uncertainty and arduousness of their everyday lives, such as in the Military Frontier. By adhering to the construction of the image of the world by applying a binary opposition of Us and Others, people would simultaneously indicate what was close or distant, known or unknown, acceptable or unacceptable, beguiling or attractive, in this way, they would construct and advertise their own identity.

\section{Closing Considerations}

So far, we have demonstrated that the Croatian folk culture most likely used the term pasoglavac (dog-headed creature) to denote the Ottomans, who have for centuries invaded Croatian lands or dwelled on its very borders. That term was used as a part of a process by which other ethnic and religious groups were ascribed certain animal/canine - i. e., inhuman attributes in order to discredit them and demonstrate that they were not "our" equals. Moreover, they were wild, deformed, beastly members or a monstrous race, which threatened our civilized society, culture, true religion - in short, our identity. Based on that, the last question can be answered - why were the texts about dog-headed creatures published in the first issues of the Journal at the turn of the 20th century? These texts were a reminiscence of the times when the Croatian lands were partly under the Ottoman rule or in constant contact with the Ottomans. Although the Ottomans were gone from the Croatian borders for over two decades, the reports about dog-headed creatures indicated which social values and norms were to be protected from the potential assaults of the monstrous Other. Also, those reports originated in the area of the Military Frontier, where the local populace exhibited their own identity by demonizing others, thereby preserving the "ethnic markings," which the ideologists and editors of the Journal strived to highlight. Moreover, in the second half of the 19th century, the whole of Europe, including the Croatian lands, was rife with "national revival" movements, which strived toward national liberation, independence, or unification (Stančić 4-25). 
The 19th century nationalistic ideologies proffered "eternal truths" about supposedly genuine symbols of national cultures, which was created by folk itself. Their goal was to transform a passive ethnic group into an active ethno-political community, into a "subject of history," which they, in part, tried to accomplish by rediscovering a personal "ethno-history" (Smith 198). The leaders of nationalistic ideological movements were not interested in studying "their own" history for its own sake, but in order to reclaim the mythical space in which "their folk's" history took place (199). Therefore, the first initiative for studying the folk was closely bound to the construction of nationalistic ideologies (Korunić 72-76). The folk thereby became an object for science, but for politics as well.

In accordance with the standards arising from the political environment of contemporary Europe, the then president of the Croatian Academy of Sciences and Arts emphasized the need to found a journal in which various happenings and changes in the life of the folk, relics of folk culture, and oral tradition, which "preserved the wit of the folk," would be published, in order so that one "could recognize one's own people, to look into its soul, study its way of thinking and understanding, its vices and virtues" (Rački 81, 83). The Academy appointed the young philologist and future politician Antun Radic ${ }^{[5]}$ for achieving that objective, who, in the second issue of the Journal, published in 1897, expounded his program of gathering the material concerning the life of the folk and clarified the purpose of the Journal. As he was aware of the current European politics and of the efforts of the Croatian and many other European peoples to achieve national independence, which was supposed to be based on genuine national cultures, Radic emphasized that the Journal was intended to publish ethnological articles. Its imperative was to study the "common folk," i. e., that stratum of the people that preserved its "ethnic markings." Radić thought that that stratum consisted of the peasants and that their culture would be the basis of the successful construction of a future Croatian nation. Therefore, it became the purpose of the Journal to search for the "truth" which, once discovered, would be further used to determine what "our" national culture is and to place it among the other cultures, "and not beneath them" (Radić 12). This project, initiated by the Academy and Antun Radić, specifically, came into existence with the publication of the first ethnological journal in Croatia. The Journal started publishing texts on folk idioms, weddings, customs, beliefs, and other segments of folk culture, which were supposed to serve as a basis for 
determining what genuine Croatian culture and identity were. The reports on dog-headed creatures fit perfectly into the purpose of the Journal. They were charged with identity values, and they originated in the area of the Military Frontier, which had preserved "ethnic markings" through the centuries. It was not very important for the process whether the Ottomans really were dog-headed creatures, but to emphasize that "we" were not. It was important to emphasize that "our" culture was Christian, steadfast, moral, heroic. However, perhaps the most important of all was to emphasize, then, at the moment when new nations were being created, that "our" culture belonged to the center, and in no way to the periphery - because, as we know, that was where the dogheaded creatures dwelled.

\section{Works Cited}

Augustin, Aurelije. O Državi Božjoj - De civitate Dei. Vol. 2, Kršćanska sadašnjost, 1995.

Barry, Quintin. War in the East: A Military History of the Russo-Turkish War 1877-78. Helion \& Company, 2016.

Begović, Nikola. Живот Срба граничара [Život Srba graničara; Life of the Serb Border Guards]. Prosveta, 1986.

Borkfelt, Sune. "Introduction: Thinking through Animal Alterities." Otherness: Essays and Studies, vol. 5, no. 2, 2016, pp. 1-12.

Bošković-Stulli, Maja. Istarske narodne priče. Institut za narodnu umjetnost, 1959.

Budasz, Rogério. "Of Cannibals and The Recycling of Otherness." Music \& Letters, vol. 87, no. 1, 2006, pp. 1-15.

Carroll, Noël. The Philosophy of Horror or Paradoxes of the Heart. Routledge, 1990.

Cohen, Jeffrey Jerome. "Monster Culture (Seven Theses)." Monster Theory: Reading Culture, edited by Jeffrey Jerome Cohen, University of Minnesota Press, 1996, pp. 3-25.

Čapo Žmegač, Jasna. "Antun Radić i suvremena etnološka istraživanja." Narodna umjetnost, vol. 34, no. 2, 1997, pp. 9-33. 
Dürrigl, Ana-Marija. "Uvod." Hrvatska Aleksandrida. Kasni odjek jednoga srednjovjekovnog romana , edited by Eduard Hercigonja and Marija-Ana Dürrigl, Matica hrvatska, 2017, pp. 7-74.

Duzer, Chet Van. "A Northern Refuge of the Monstrous Races: Asia on Waldseemüller's 'Carta Marina."' Imago Mundi, vol. 62, no. 1, 2010, pp. 221-31.

Đorđević, Tihomir. Српске народне приповетке и предања из Лесковачке области [Srpske narodne pripovetke i predanja iz leskovačke oblasti; Serbian Folk Tales and Tradition in Leskovac]. Srpska akademija nauka i umetnosti, 1988.

Filakovac, Ivan. "Vjerovanja (Retkovci u Slavoniji)." Zbornik za narodni život i običaje Južnih Slavena, vol. 10, no. 1, 1905, pp. 144-49.

Filipović, Milenko. “Живот и обичаји народни у Височкој Нахији” [“Život i običaji narodni u Visočkoj nahiji”; “Traditional Life and Customs in Visočka Nahija”]. Srpski etnografski zbornik, vol. 61, 1949, pp. 1-336.

Friedman, John Block. The Monstrous Races in Medieval Art and Thought. Syracuse University Press, 2000.

Gellner, Ernest. Postmodernizam, razum i religija [Postmodernism, Reason and Religion].

Translated by Silva Mežnarić, Jesenski i Turk, 2000.

Gilmore, David. Monsters: Evil Beings, Mythical Beasts, and All Manner of Imaginary Terrors. University of Philadelphia Press, 2003.

Grgin, Borislav. "The Ottomans and Croatia at the End of the Middle Ages (1458-1526)." Glimpses of Balkans: Cultural History, edited by Abidin Temizer, Gece Kitaplığı, 2017, pp. 3-15.

Hercigonja Eduard, and Marija-Ana Dürrigl, editors. Hrvatska Aleksandrida: kasni odjek jednoga srednjovjekovnog romana. Matica hrvatska, 2017.

Hirc, Dragutin. "Pasoglavci." Zbornik za narodni život i običaje Južnih Slavena, vol. 1, 1896, pp. 229.

"Hirc Dragutin." Hrvatska enciklopedija, mrežno izdanje. Leksikografski zavod Miroslav Krleža, 2021, www.enciklopedija.hr/Natuknica.aspx?ID=25712. Accessed 10 Feb. 2021. 
"Hrvatska akademija znanosti i umjetnosti." Hrvatska enciklopedija, mrežno izdanje. Leksikografski zavod Miroslav Krleža, 2021, www.enciklopedija.hr/Natuknica.aspx?ID=26392. Accessed 4 Mar. 2021.

Jaritz, Gerhard. "From the Peripheries to the Centers and Back: Visual Culture and the Edges of this World." The Edges of the Medieval World, edited by Gerhard Jaritz and Juhan Kreem, Central European University Press, 2009, pp. 21-38.

Jokić, Jasmina. “Демонско биће псоглав у усменој и писаној усмености рећи” [“Demonsko biće psoglav u usmenoj i pisanoj umetnosti reči”; "Demonic 'Dog-head' Creature in Oral and Written Literature"]. Жива реч [Živa reč], edited by Mirjana Detelić and Snežana Samardžija, Balkanološki Institut SANU, 2011, pp. 257-69.

Kastoryano, Riva. "Codes of Otherness." Social Research, vol. 77, no. 1, 2010. pp. 77-100.

"Kinokephaloi." Theoi, www.theoi.com/Phylos/Kunokephaloi.html. Accessed 14 Mar. 2021.

Kocój, Ewa. "European Representations of Others: Reflecting on the Us and Them: An Intricate History of Otherness Exhibition and Book." Anthropos, vol. 108, no. 1, 2013, pp. 273-77.

Korunić, Petar. Jugoslavizam i federalizam u hrvatskom nacionalnom preporodu. Globus, 1989.

Krmpotić, Ivan. "Pasoglavci." Zbornik za narodni život i običaje Južnih Slavena, vol. 11, no. 1, 1906, pp. 157-58.

Levanat-Peričić, Miranda. Uvod u teoriju čudovišta: Od Humbabe do kalibana. AGM, 2014.

Mandeville, John. The Travels of Sir John Mandeville. The version of the Cotton Manuscript in Modern Spelling. Macmillan and co. Limited, 1900.

Mencej, Mirjam. Styrian Witches in European Perspective: Ethnographic Fieldwork. Palgrave Macmillan, 2017.

Moačanin, Fedor. Radovi iz Povijesti Vojne krajine. SKD “Prosvjeta," 2016.

Mosely, Charles. "The Travels of Sir John Mandeville and the Moral Geography of the Medieval World," PORTAL Journal of Multidisciplinary International Studies, vol. 12, no. 1, 2015, pp. 1-12. 
Olszewska, Anna. "Katalog" ["Catalogue"]. My i oni. Zawiła historia odmienności [Us and Them: An Intricate History of Otherness], edited by Karolina Grodziska and Barbara Górska, Państwowy Instytut Wydawniczy, 2011, pp. 46-249.

Paul the Deacon. History of the Langobards. Translated by William Dudley Foulk, University of Pennsylvania, 1907. Internet Archive, web.archive.org/web/20070212074645/

http://www.northvegr.org/lore/langobard/index.php. Accessed 14 Mar. 2021.

Primorac, Jakša. “Arhivska građa Odsjeka za etnologiju HAZU.” Zbornik za narodni život i običaje, vol. 55, 2010, pp. 9-38.

Pseudo-Callisthenes. "A History of the Great World Conqueror, Alexander of Macedon." The Romance of Alexander the Great by Pseudo-Callisthenes. Translated by Albert Mugrdich Wolohojian, Columbia University Press, 1969, pp. 23-187.

Rački, Franjo. "Svečano slovo." Ljetopis Jugoslavenske akademije znanosti i umjetnosti, vol. 4, 1889, pp. 76-85.

Radić, Antun. "Osnova za sabiranje i proučavanje građe o narodnom životu." Zbornik za narodni Život i običaje Južnih Slavena, vol. 2, 1897, pp. 1-88.

Rehn, Dana. "Going to the Dogs: The Foreign and Religious Other in German Renaissance Prints." Otherness: Essays and Studies, vol. 5, no. 2, 2016, pp. 111-50.

Rotman, David. "At the Limits of Reality: The Marvelous in the Medieval Ashkenazi Hebrew Folktales." The Hebrew Story in the Middle Ages II, special issue of Jewish Studies Quarterly, vol. 20, no. 2, 2013, pp. 101-28.

Said, Edward W. Orijentalizam: zapadnjačke predodžbe o Orijentu. Translated by Rešid Hafizović, Svjetlost, 1999.

Sardelić, Mirko. “Europski klerici i misionari o Mongolima: percepcija stepskih barbara u Europi sredinom 13. stoljeća." Zbornik Odsjeka za povijesne znanosti Zavoda za povijesne i društvene znanosti Hrvatske akademije znanosti i umjetnosti, vol. 29, 2011, pp. 1-21.

Shafer, Robert. “Unmasking Ktesias' Dog-headed People." Historia: Zeitschrift für alte Geschichte, vol. 13 , no. 4,1964, pp. 499-503. 
Smith, Antony D. Nacionalni identitet. Translated by Slobodan Đorđević, Biblioteka XX vek, 2010.

Stančić, Nikša. Hrvatska nacija i nacionalizam u 19. i 20. stoljeću. Barbat, 2002.

Šešo, Luka. "Which Woman is a Witch? The Stereotypic Notions about Witches in Croatian Traditional Beliefs." Studia ethnologica Croatica, vol. 24, no. 1, 2012, pp. 195-207.

Šešo, Luka. Živjeti s nadnaravnim bićima: vukodlaci, vile i vještice hrvatskih tradicijskih vjerovanja. Jesenski i Turk, 2016.

Šmitek, Zmago. "Gog and Magog in Slovenian Folk Tradition." Christian Demonology and Popular Mythology: Demons, Spirits, Witches, edited by Gábor Klaniczay and Éva Pócs, vol. 2, Central European University Press, 2006, pp. 237-49.

Tylor, Charles. Sources of the Self: The Making of the Modern Identity. Harvard University Press, 1989.

Valk, Ülo. "Folk and the Others: Constructing Social Reality in Estonian Legends." Estonian Approaches to Cultural Theory: Approaches to Cultural Theory Series, edited by Valter Lang and Kalevi Kull, vol. 4, University of Tartu Press, 2008, pp. 222-38.

Visković, Nikola. Životinja i čovjek. Prilog kulturnoj zoologiji. Književni krug, 1996.

William, Arens. The Man-Eating Myth: Anthropology and Anthropophagy. Oxford University Press, 1979.

Wolohojian, Albert Mugrdich. "Introduction." The Romance of Alexander the Great by PseudoCallisthenes. Translated by Albert Mugrdich Wolohojian, Columbia University Press, 1969, pp. 122.

Zovko, Ivan. "Vjerovanja iz Herceg-Bosne." Zbornik za narodni život i običaje Južnih Slavena, vol. 6, 1901, pp. 115-60. 
[1] This paper has been supported by the Catholic University of Croatia under the project "Otherness as the Social and Cultural Determinant of the Croatian Past," no. HKS-2017-7; and by the Croatian Science Foundation under the project "Narrating Fear: From Early Records to New Orality," no. IP-06-2016-2463.

[2] For more on the Journal itself and on its significance for Croatian ethnology, see Primorac.

[3] The Croatian word pasoglavac is a compound of "pas" - dog and "glava" - head.

[4] Hirc's short text on dog-headed creatures I transcribe here in full: „U sv. Petru kod Ludbrega pričaju, da je pred selom bila nekoć velika močvara (berečin). Dok je Turčin Hrvatskom vladao, bio je neki pasjan, koji je izgledao sasvim kao čovjek, samo je imao pasju glavu. Hvatao je ljude, no najvolio je ženama odgristi sise. Ljudi su, bježeći pred njime po berečini, bacali pred sobom daske, da lakše uteku. U Velikom Trgovišću (Zagorje) zovu pasoglavca pesjak. 'Ima - kažu - jedno oko sredi glave; hudi človek, koj kršćane lovi, jede i ob tom žive'. U Slatniku kod Broda na Savi zovu pesjaka pasjoglavac. 'Ima pasju glavu, jedno oko i rep. Jede kršćane i nalazi se u mračnoj zemlji. U Rusiji uvijek topovi pucaju, da ne uzmogne k nama'. U Selištu u Moslavini zovu ga songlav. U Babinoj gredi plaše djecu pasoglavcem, a pričaju da su mu noge od vratila; dočim u Strizivojnoj kažu, da ima pasju glavu i konjske noge, i da je jeo svijet. Jedan seljak iz Gornjih Boraca kod Daruvara pripovijedaše mi o pasoglavcima, da ih ima u mračnoj zemlji, a pred njima da se može čovjek sakriti u konjsko djubre, jer ga drugačije nanjuše. Tu mračnu zemlju čuva vojska, da ne prodju k nama, već Rusku carevinu. U toj mračnoj zemlji ima dragog kamenja. Pasoglavci odvedoše onamo čovjeka, nu taj je utekao i odnio dragoga kamenja, i tako se naš narod uvjerio, da ga ondje ima. Toga čovjeka htejde da uzme pasoglava žena, nu je bijaše posljednja, pobjegne joj. U Markušićima u Žumberku znadu takodjer za pasoglavca. Velik je kao čovjek, tijelo ima čovječje s četiri noge. Glava mu je kao u psa a na vrha glave jedno oko“. ("In the village of Sv. Petar by Ludbreg, they say that there used to be a great swamp by the village. When the Turks ruled over Croatia, there was a pasjan, who appeared entirely as a man, but his head was like that of a dog. He would attack men, but he liked to bite off women's tits most of all. People would, while running away from him through the swamp, throw planks before their feet, so that they could escape more easily. In Veliko Trgovišće (Zagorje), they call a dog-headed creature a pesjak. 'He has - they say 
- one eye in the middle of its head; a terrible man, who attacks Christians, eats them and so sustains himself.' In Slatnik by Brod na Savi they call a dog-headed creature a pasjoglavac. 'He has the head of a dog, one eye and a tail. He eats Christians and lives in a dark country. In Russia cannons are constantly blazing, to keep him from coming to us.' In Selište in Moslavina they call it a songlav. In Babina Greda they scare children with stories of the dog-headed creature, saying that his legs are like axles; meanwhile, in Strizivojna they say that it has the head of a dog and the legs of a horse, and that it eats people. A peasant from Gornji Borci near Daruvar once told me about the dogheads, saying that they live in a dark country, and that one can hide from them by hiding under horse manure, because otherwise they would catch his scent. This dark country is guarded by an army, so that they cannot come to us, but they do go into the Russian Empire. There are many gemstones in that dark country. Once the dogheads abducted a man and took him there, but he escaped and brought gemstones home with him, so our people learned that there are gemstones there. One dog-headed woman wanted to take that man as her husband, but he managed to get away from her because she was very slow. In Markušići in Žumberak they also know of the dog-headed creature. It is as tall as a man; its body is human, and it has four legs. His head is like that of a dog, and on top of his head he has one eye"; my trans.; 229).

[5] Ivan Zovko's text on the dog-headed creatures I transcribe here in full: „Dok su 'soglavi po svijetu hodali, nigdje nije mogo od njih grob ni mezar ostati. Koliko mu drago da se mrtvac ukopa u zemlju, oni bi zemlju rasprčkali I otkopali mrca, pa ga izjedli i pojeli. Kad već ljudi tome jadu nijesu mogli nikako drugačije stati - pa što sve samo nijesu probali - onda su počeli stećke mećati. Od tada, kaku su počeli to činiti, malo su dušom odahli i otpočinuli, jer im više nijesu 'soglavi dodijavali, ni mrtve im nisu kopali ni jeli. Kad oni (mrtvi) nikom ništa ne rade, niti na put kome staju, neka niko njiha ne uznemiruje u njihovoj vjekovječnoj kući“. ("When the 'soglavs were wandering about, no grave nor mezar [Muslim grave] was safe from them. No matter how deep the deceased were buried, they [the 'soglavs] would scatter the earth and unbury them and gnaw on them and eat them. As people knew no other way of stopping that - and they tried everything - they started placing menhirs. Since they started doing that, they could rest a little easier, because the 'soglavs did not disturb them anymore, nor did they unbury or eat their dead. For they (the dead) do not disturb anyone, and therefore no one should disturb them in their eternal homes"; my trans.; 142). 
[6] I transcribe the text here in full: „Pasoglavci: Svet kazue, da na zemlje nea pasoglavaca, al da se taka nagrda, nakaza more rodit. Tako danaske se pripoveda, kako e negda u Retkovci bila niaka baba Đurđa Stefanovića. Ko mlada snaša postane noseća. Je li bilo od Boga iliti od zloga, snaša Đurđa rodi muško dite, koe se od straote ni moglo gledat: imalo na sebe tela i pasjeg i svinjećeg i telećeg. Mat je, kažu, dete utušila i za kaštigu najprije bila kanđana, ponda odedila rešta puno godina. Za sve takve ovdike nakaze veli svet, da su roditi od božje volje, da mater kaštigue, ako se noseća klela sa svoim porodim, iliti da kaštiga kog u rodu s detetim“. ("Pasoglavci: People say that there are no dog-headed creatures in the world, but that such abominations can be born. These days, there are rumours about a crone called Đurđa Stefanović, who used to live in Retkovci. When she was a young maiden, she became pregnant. Whether by God's or the Devil's work, young Đurđa gave birth to a male child, which was too horrible to behold: its body parts resembled those of a dog, a pig and a calf. Its mother, they say, smothered the child, and for that crime she was first scourged, and then imprisoned for many years. For all such abominations people here say that they were born by God's will, in order to punish the mother for swearing upon the child in her womb while she was pregnant, or to punish someone related to the child"; my trans.; Filakovac 148).

[7] Here I transcribe the main part of Krmpotić’s text: „U Općini osičkoj u Lici pričaju o pasoglavcima ovako: Oni su imali oko samo jedno na vrh glave i kozje noge. Bio jedan čovjek pa mu umrla žena i ostalo mu dvoje djece. On uzeo drugu, a maćeha in nije mogla vidjeti, pa kad njega nije jednom bilo kod kuće, protjera ih u svijet. A djeca idu, idu, pa dođoše u jednu dragu, a u dragi kuća na šiljak. Kad oni unutra, al baba pasoglavica, oko joj na vrh glave, a u nje kozje noge. Ona šteknu pa progovori: 'Što bi va rada?' Vele: 'Gladni smo, daj nam, bako, što jesti'. Ona im donese zdjelu punu mesa i jednu ruku. a, vele, mi to ne možemo jesti, a onda im da mlijeka i kruha. E, veli, nisu dobro došli: sad su moji sinovi otišli u lov, pojest će vas, ajte se u peć sakriti. Došli oni kući, štekću; tu mora negdje biti krštena duša. Veli baba: Ne, nije, A oni; jest, tu mora biti. - 'E, veli ona, ako ste tvrde vjere, kazat ću vam, nemojte ih odmah pojesti, hranit ćemo ih'. - 'Aja, vele oni, ne ćemo. Jedno ćemo peći, a jedno variti' . . . A kad su došli do jedne kolibe, nisu htjeli namah ući. Ne ćemo, vele, uči k njima, nego ako se stanu križati. A kad su se stali križati, odoše k njima. Kad oni u kuću, ukućani ih pitaju, od kuda su, šta su?' A oni im rekoše: tako i tako i tako. 
'Ajte, vele, kući. otac vam je umr'o, a maćeha na kome štrama visi'. Djeca brže bolje doma pa potpale, a ona izgori“. ("In the county of Osik in Lika, of dog-headed creatures they recount thusly: They had only one eye on top of their heads and legs like those of a goat. There was a man, and his wife died and left him with two children. He took another [wife], and the stepmother could not bear to see them [the children], so one day when he was away from home, she chased them away. And the children went wandering, and they wandered until they came upon a valley, and in that valley, there was a house with a pointy roof. They went in, and lo! a dog-headed crone inside, one eye on top of her head and her legs like those of a goat. She barked and said: 'What do you want?' They said: 'We are hungry, grandmother; give us something to eat.' She brought them a bowl filled with meat and an arm, but they said, oh, we cannot eat that, and then she gave them some milk and bread. Alas, she said, you came at a bad time: my sons are out hunting, they will eat you, go and hide in the furnace. They [the sons] came home, barking: there must be a christened soul somewhere in here. The crone said: No, there isn't. And they: yes, there has to be. - 'Eh, she said, if I can rely on you, l'll tell you [where they are], but don't eat them right away, we'll fatten them up first.' - 'No can do, they said, we won't have it. One we will roast, and the other one cook' . . And when they came upon a hut, they would not go inside right away. We won't, they said, go inside, unless they [the people inside] start to cross themselves. And when they started crossing themselves, they [the children] went to them. When they came inside, the inhabitants asked them, where did they come from, who are they. And they [the children] told them how it was. 'Go home, they [the inhabitants] told them, your father is dead, and your stepmother is whoring about.' The children hurried home and set the house on fire, and she burned in it”; my trans.; 157-58).

[8] For a general overview of the ideas and the constructs of monsters in Western culture, see Cohen, Gilmore, William. For more on the perception of monstrous races in the antiquity, and especially in the Middle Ages, see Friedman, Jaritz, Levanat-Peričić. Regarding the perception of them in the European early modern age, see Duzer, Rehn, Budasz.

[9] Considering that books such as Alexandrida were owned (and read) by wealthy burghers, litterati and literate members of the clergy (Dürrigl 7, 20-21), further research should examine how the dog-headed creatures from the Alexandrida found their way into the ideas of the common folk 
of which the examples listed in the Journal speak. This problem will not be dealt with here, due to spatial constrictions and this paper having a different objective.

[10] For more on the chronology of emergence of various versions of the Alexandrida in the South Slavic area, see Dürrig 21-22.

[11] The version closest to the now lost original is considered to be the Alpha Group of manuscripts, which includes the 4th century Latin translation by Julius Valerius and the 5th century Armenian translation. Although it is newer, the Armenian translation is considered to be the best rendering of the original (Wolohojian 2), and therefore I cite it in this paper.

[12] At the same time, a similar example was recorded among the Orthodox people living in central Bosnia and Hercegovina: „Православци верују да је Русија на крају света и да је тамо мрачни вилајет. У том вилајету има псоглава, људи са пасјом главом који нападају на све људе и сваког дана је Русија пуцала на њих неколико хиљада топова и у задње доба озидала бедем". ("The Orthodox believe that Russia is at the end of the world, and that there is a dark province there. There are dog-headed creatures in that province, people with canine heads who attack all people, and every day Russia fires several thousand cannons at them and lately they have built a wall around that province"; my trans.; Filipović 213).

[13] Legends according to which a king's/emperor's daughter gave birth to a dog-headed creature after having sexual relations with a dog are present in the traditional culture of the wider Southern Slavic circle, including Croatian Istria, where the dog-headed creature born in that manner was identified as Attila the Hun, who devastated the neighboring Northern Italian cities in the 5th century (Bošković-Stulli 126-27, 190-94). Although Attila was not Ottoman, both of those characters are variants of the same subject, one that was used to demonize the undesirable Other.

[14] For more on the notion of "antemurale christianitatis," especially in Croatian history, see Grgin.

[15] For more on the political career of Antun Radić, see Perić. Regarding his contributions to Croatian ethnology, see Čapo Žmegač.

\section{(c) (7) $(9)$}

Creative Commons Attribution-NonCommercial-NoDerivatives 4.0 International License 